Александар Петровић ${ }^{1}$

Филолошки факултет

Универзитета у Београду

Данко Камчевски ${ }^{2}$

Филолошко-уметнички факултет

Универзитета у Крагујевцу

Александра Стевановић ${ }^{3}$

Филолошки факултет

Универзитета у Београду
UDK: 821.111.09-21 Шекспир В.

821.134.2.09 Сервантес С. М.

https://doi.org/10.18485/imp.2017.ch.12

\title{
ДОНКИХОТИЗАМ БЕЗ КРАЈА
}

Свака игра подразумева прихватање неке илузије. Речник технологије

Па зар ниси, привиде кобни, и опипљив тако што си видљив оку.

Магбет

Овај рад је покушај да се у перспективи културне антропологије сагледају Сервантес и Шекспир као два витална пророка европске културе. Идеја је да се изместе из свог времена и да их начелом најмањег могућег привида кроз црвоточно време преведемо у свет у коме живимо. Шта су они заиста мислили остаје наравно заувек изван могућности сазнања, али њихов магнум опус сагледава се као питање деконструкције границе истине и обмане из чега настаје привид сваког привида - технологија. Њихови књижевни ликови су прешли преко свих граница и показали исходе живота изван равнотеже у коме пала етика драматургијом историје заузима позу маштоглаве технологије.

Кључне речи: етика, равнотежа,технологија, Дон Кихот, Магбет, Европа.

\footnotetext{
1 petralist@gmail.com

2 dkamcevski@gmail.com

3 aleksandrastevanovic@yahoo.com
} 


\section{1. Витез - то је човек на Западу}

Мигел де Сервантес у уводу Маштоглавог идалга дон Kихота од Манче каже да је та књига:

„.... цела само оптужба на рачун књига витешких којих се Аристотел никада није сетио, нити је о њима икад ишта рекао свети Василије, нити је до њих дошао Цицерон, нити под њене баснословне бесмислице потпадају тачности истине, ни запажања астрологије, нити су јој важне геометријске мере, ни побијање аргумената, чиме се служи реторика, нити има разлога да било коме придикује, мешајући људско са божанским, а то је она врста мешавине којом се неће заоденути ниједна хришћанска памет.“" (Сервантес 2011: 22).

Оно што је Сервантес на основу ерудиције и интуиције закључио потврдила је Елизабет Арчибалд, један од ауторитета за артуријанске легенде и средњовековне витешке романе, када је рекла да „нема расправе о романси као жанру код књижевних критичара или реторичара у античком добу“ (Арчибалд 2008: 10-11). Иако су приче о потрагама за идеалитетом и виртуелним идентитетом постојале и пре витешких романа, нико их тако није звао. Реч романса којом се служи Арчибалдова је изворно означавала искључиво витешке романе, да би потом почела да се употребљава као општи појам најпре за приче о авантурама и напослетку за скоро сваку авантуристичку причу са елементима чудесног. Теоретичари су се трудили да на више начина подупру ову апстрактну дефиницију и порекну самосвојност витешког романа. Тако су Бруер (1988) и Вилсонова (1976) указивали на подсвесно као најмањи заједнички чинилац прича и притом се служили мало Фројдовом психоанализом, а мало Јунговом аналитичком психологијом. Барон (1987) у својој књизи о средњовековним витешким романима у Енглеској такође расплињује врло конкретан жанр тврдећи да у темељу ових и сличних приповести лежи идеолошки мотив: све оне говоре о сновима о бољем животу и прогресу. Ернст Блох (1988) нешто слично тврди када говори о односу утопијског мишљења, са једне стране, и књижевности и уметности, с друге. На сличном фону је антрополошко разумевање Лене Петровић (1999) која иде ка свођењу на основне приче - митове; овом учењу припада 
и Нортроп Фрај који у Анатомији критике (2007) тврди да постоје четири основна мита у која се могу уклопити остали жанрови.

Ови истраживачи имају своје опоненте, који насупрот редукцијама и генерализацијама, супротстављају врло специфичне одлике витешких романа због којих они никако не могу бити тумачени као бајке и митови у новом руху. Мелетински (2009) је јасном и строгом анализом одвојио витешки роман од других књижевних форми попут бајке, романа, епа. Ауербах (2003) је у Мимезису урадио слично нагласивши аристократске слојеве и дефиницију витеза као човека који иде у авантуру. Стивенс (1974) варира овај увид тврдњом да је за писце витешких романа човек као човек - биће авантуре запитано над смислом свог постојања. Винавер (1971) је витешки роман упоредио са катедралом, а његовог протагонисту са статуама на готским катедралама које се утеловљују и издвајају у односу на фасаду, попримајући индивидуалност у односу на статуе старијих времена које су се стапале са зидовима катедрале. Последње поређење је нарочито корисно. Колико је витешки роман сложена појава по свему налик на катедралу, толико је и његов главни јунак човек који у ту катедралу посвећено иде. Није никакво чудо што се пре средњег века није чуло за витешке романе или што је након њега ова форма почела да бледи, добија нејасне контуре и постаје све општија, постаје романса, фантазија, авантуристичка прича, пикарски роман, готски роман и бројне друге рекомбинације.

Ако се сложимо са другом групом теоретичара и Сервантесовом интуицијом, избећи ћемо закључке да је од памтивека до данашњих дана реч о једној истој причи. То би значило да се Сервантес обрачунава и са бајкама и са митовима и са еповима, што је до краја нетачно. Злосрећни Одисеј није јурио своју авантуру, већ су му богови отежавали повратак кући. Јунак бајке се најчешће невољно упушта у било какве походе а неправду исправља јер му од тога зависи живот. Тек код протагонисте витешких романа имамо појединца који без икакве потребе да штити заједницу или себе иде у пустоловину да би се доказао. Његов етос је хришћански, што се природно слаже са стањем ствари у средњем веку на Западу. Послушајмо Сервантеса:

„Хоћу да кажем да редовници, и поред свег мира и спокоја, од неба траже добро на земљи, али ми војници и витези извршавамо оно што 
небеса траже, бранећи земљу снагом мишице и оштрицом мача, и то не испод жита, него на светлу дана, изложени несносним зрацима сунца лети и оштрим бодљама леда зими. Тако смо ми службеници Божји на земљи и рука којом се на њој извршава његова правда." (Сервантес 2011: 119).

Дакле, једино ако као претпоставку узмемо да је витешки роман посебан жанр sui generis и да одражава метафизичке и етичке аспекте средњовековне епохе, бићемо у стању да разумемо Сервантесову критику. Сви покушаји да се витез представи као још један 'јунак бајке', 'просечни човек', ‘човек уопште' заправо одсликавају невољност културе Запада да се погледа у огледало и види себе. Она покушава да себе уопшти и своја највећа дела прикаже као визију неког човека свих епоха. Зато ми децидно тврдимо: витез - то је човек на Западу. Он је идеал којем треба тежити. Када Сервантесов Дон Кихот изнова уздиже витешке идеале, а уз то смо свесни да је реч о човеку који је пореметио памећу, видимо колико је у ствари Сервантесова књига критика не само једног жанра са много лоших књижевних дела ${ }^{4}$ већ, боље речено, свођење рачуна са западноевропском културом на прагу новог века и човеком којег она жели да произведе. Драма Дон Кихота није драма кинеског, арапског, руског или абориџинског човека, већ искључиво драма коби западног човека омађијаног појмовима, апстракцијама, идеалитетима. И у новом веку остала је та тежња апстрактном идеалитету, али уместо витеза пустолова који осваја и ослобађа, појавио се научник који једнако пустоловно осваја непознато и ослобађа скривене тајне девичанске природе. Он је изгурао витеза с позорнице и сам публици прибавља узбуђење и разоноду. У години када пишемо ову кратку расправу обележава се четири стотине година од смрти Мигела де Сервантеса; али не само њега, већ и енглеског драматурга, Вилијама Шекспира. Њихови животи се нису поклопили само површно, на нивоу датума, већ дубински, у погледу разумевања суштине доба открића.

4 Сервантес своју оштрицу усмерава на лоше (и популарне) витешке романе, а не на велика дела попут, рецимо, Кретјенових романа.

300 


\section{2. Химере и фантазми дон Кихота и Магбета}

Хосе Ортега и Гасет, један од најзначајнијих шпанских мислилаца, говори о томе како „одавно већ, примећујући то или не, западни човек не очекује ништа од књижевности и поново је гладан идеја, јасних и видљивих, о важним стварима“ (Ортега и Гасет 1980: 25). Данас ту глад задовољавају наука и технологија, које се махом не преиспитују, већ их верна публика узима здраво за готово као некада витешке романе. Наука и технологија окренуте су идеалитету будућности - Хамлетовим речима „ишчашене из зглоба“ имају једини циљ: победити зле силе природе и створити будућност у којој ће владати умишљени идеалитет. Све што није део такве будућности, технологија не признаје. С друге стране, глад за будућношћу доводи до судара са светом и непрестане кризе различитих неспоразума јер аутономија технологије не допушта свету да буде то што јесте. Он је увек предмет тумачења да би могао да буде предмет интервенције и ослобађања од злих сила.То свакако води губљењу равнотеже, као и у случају велеумног племића од Манче, који се завршава замором и поразом; или, као што је случај с Шекспировим Магбетом, води крвавом сукобу с људима и њиховим светом. Моћ коју Дон Кихот и Магбет осећају у својој борби иста је она коју човек осећа док покорава природу и генерише виртуелни технолошки живот. Магбет је прешао све етичке границе да би се докопао апсолутне моћи, као што и модерни човек прелази преко свега да би се наметнуо као господар природе. Дон Кихота у његовим бојевима са светом води идеалитет Дулсинеје у коме он чезне да разреши противречност емпиријске ругобе живота и лепоте последњих времена. Први покретач историје, како је схваћена од слуђеног Дон Кихота до рационалних француских просветитеља, јесте фантазам идеалне девице у коме ће бити превазиђене све историјске невоље. Ослобађање Дулсинеје из затворене куле врло је слично ослобађању племенитих дивљака од њихове заосталости и подастирање апотеози модернизације. Срећом по њу, Дон Кихот није успео да ослободи Дулсинеју, док су сви они небројени Индијанци, Зулу ратници, Абориџини, Ескими и ини домороци ослобођени свега што су имали, па и самог живота. 
Наличје света моћи увек је нека технологија историје. Дон Кихот преузима улогу некога ко би требало да промени свет и да раскринкавајући зле чаробњаке успостави праву историју. Иако алтруиста по својим основним мотивима, он је жељан славе и хвале, исто као и Магбет. Дон Кихот и Магбет су два комплементарна лика, шкотски емпиризам моћи Магбета складно се допуњава шпанским идеалитетом моћи. Реч је о једној истој појави и истом узрочнику проблема: обрачун са светом, а да се ништа није покушало са самим собом. Према феноменологији Михајла Петровића Аласа „нешто слаби утолико јаче уколико се више шири“ (1933: 3). Магбет врло брзо отима круну, „златни обруч“, у нади да је то највећи степен његове моћи, да је стигао до разрешења свих историјских противречности; међутим, тим насилним присвајањем и ширењем моћи, он разара вредности и сурвава се у пропаст где се његова снага изгуби у часу најављене смрти. Са друге стране, али у истој равни, Дон Кихот све силније насрће на ветрењаче за које мисли да су дивови, и тако све више губи тло под ногама и улази у све неподношљивије неприлике.

Дон Кихотова и Магбетова опсесија игром моћи одређује њихову судбину. И у једном и у другом делу, као у камери опскури, свет је изврнут наопако, или како суђаје у Магбету најављују: „Лепо је ружно, ружно лепо“. У тој протодеконструкцији долази до разарања ума и код једног и код другог лика - код једног се то огледа у крвожедној страсти за нечим историјски битним као што је круна, док Дон Кихот супротно, али комплементарно „витешки“ жуди за идеалном девицом. Међутим, као предмети жудње круна и девица су исто - једна иста тежња да се под привидно различитим изговорима пролије крв јесте основни покретач доба открића. Никола Милошевић у раду „Дон Кихот и нихилизам“ истиче да су „етичка стремљења инструмент јунакове лудости“. ${ }^{5}$ И код једног и другог лика у страсној жељи да се пролије крв праведника и девица долази до губитка мере. Без равнотеже Дон Кихот и Магбет се руше, и то више уколико необузданије пројектују слике: док један види дивове које мора да обезглави да би дошао до крви девице, други види власт чије одржање

5 Видети: Н. Милошевић, Дон Кихот и нихилизам, Антрополошки есеји, Београд: Нолит, 104-129.

302 
стално тражи још крви. „Свака игра подразумева прихватање неке илузије“ (Речник технологије 1981: 8).

Магбетовска и донкихотовска игра почињу у тренутку када потпуно прихвате своје илузије и на лажном идентитету уђу у пројекције борбе са светом. Дон Кихот није прави витез, Магбет није прави краљ. У први мах се чини да ће успети да наметну свој лажни идентитет, да ће добити историјску игру и истрајати у борби, али једино што њихове победе доносе је пораз. Слично је и са модерним научником који у себи носи чврсто сплетен дух Дон Кихота и Магбета. И све његове победе су порази.

„И ово има једну опасност између осталих: угледавши свет човек се налази окружен баснословном гомилом предмета и поступака створених технологијом која чини главни пејзаж, тако згуснутим да скрива иза себе праву природу. Може да дође до тога да човек изгуби свест о технологији и приликама, на пример, моралним у којима она настаје враћајући се као првобитни човек томе да уњој не види друго до природне дарове. Тако је чудесно ширење технологије учинило да се она прво истакне над трезвеним репертоаром наших природних радњи и дозволило је да стекнемо пуну свест о њој, али затим, настављајући у фантастичном прогресу, њен раст прети да наоблачи ту свест." (Ортега и Гасет 1980: 34).

Мрак, злослутно крештање птица и грмљавина у Магбету су права слика збивања у главном јунаку драме, али засигурно говоре и о побуни природе над насилним и фантазмагоричним делима два јунака, удруженим да на Западу направе Научника. Као одговор на то чак и сама природа устаје: Бирмингемска Бирнемска шума, противно свим рационалним очекивањима, креће према Дансинејну што води паду Магбета, како би се поново успоставила равнотежа коју је он „ишчашио“ својим властољубљем.

Коста Стојановић током страшног српског ратног сукоба с Аусторугарском каже да „химере воде у пропаст“ и истиче значај моралних начела која покрећу свет упозоравајући да ,,ако прогрес треба да буде по цену гажења свих светиња, боље је и да нема никаквог прогреса“ (Стојановић 1920: 1105). Међутим, прогрес је ратна застава техноло- 
гије, а човек - технолог, као ни Магбет, не мари за број жртава. У тој борби спреман је да сасече саму природу као што је Дон Кихот спреман да се разрачуна са свим утварама своје маште на свом путу. Природа је за технолога само див кога би мачем требало покорити. Жак Елил долази до закључка „сведоци смо стварања нове технолошке етике која има сопствене вредности“ (Елил 1962: 396). Због тога и нисмо у стању да разлучимо колико дубоко смо морали да потиснемо етику да би се на том неуротичном потискивању развила технологија. Што више стварна природа покушава да се приграби, а природа ствари замени виртуелним опсенама, то свет више ишчезава претварајући се у борбу „пуну буке и беса, која не значи ништа“. Значења нису ни важна, јер је Френсис Бекон као пророк научне револуције описао „Магбета научника“, који непрекидно трага и осваја природу, али никада се не пита зашто. „Никада нисмо били готови да одговоримо на питање 'Због чега?'. И сада, када се приближавамо стварности и сама средства тврде да су сврха, наше алатке постају наши господари, и најснажније од њих постају претња и самој нашој егзистенцији." (Тилих 1980: 79).

Отуда „свет није ништа друго до низ потенцијалних оруђа и ресурса“ (Варк 2015). Док су научници у заносу изоштравали научни метод којим ће овладати природом, ретко ко се од њих сетио да укаже на свест о мери и самоограничењу. „Етичка свест је природна противтежа развоју науке - ако се жели брзи развој науке, неопходно је пригушити савест." (Деспић и Петровић 2001: 159). Вођен Декартовом идејом „Ја мислим, дакле Ја постојим“ из чега следи - ја могу све зато што мислим - човек није у стању да сагледа своје границе и преиспита могућности научног освајања. Због чега ми свакога дана морамо да „побољшавамо“ свет и осмислимо нови технолошки изум да бисмо кроз Декартову мисао потврдили своје постојање? Дон Кихот и Магбет су одлучили да се страсно предају свом Ја да би тако постали велики симболи доба открића које у 16. веку отпочиње своју пустоловину - откривање неоткривеног и освајање неосвојеног. У тренутку када Дон Кихот и Магбет крећу у остварење својих циљева, они их не преиспитују, већ сматрају да се њихов напор сам по себи разуме. Исто се дешава човеку технологу који не може да застане јер га чека 
много млинова које мора да спрегне и много моралног отпора који мора да сломи у све већу славу напретка. „,Трагедија модерног света у погледу интелекта и културе је то што се налазимо у једном технолошком миљеу који не допушта да размишљамо. Ми не можемо да погледамо у прошлост и размотримо је." (Елил 1990: 145). Откриће је постало предуслов модерног човека. У њему се пробудила жеђ коју гаси само искоришћавање откривеног и вера да ће свет новим технолошким изумима постати боље, удобније место, чак ако ни самог човека у њему не буде било, већ једино виртуелних утвара и химеричних бића.

Из овога се већ види зашто Магбет убија краља и отима круну, и због чега Дон Кихот почиње да живи у уобразиљи. Обожавање круне као симбола највише моћи у Магбету нимало се не разликује од идолатрије научно-технолошких открића која ће физичким огледима у подземним бункерима обезбедити неопходну власт над природом и њеном „божанском честицом“. Дон Кихот је несумњиво предузимљиво - проналазачког духа. Он креће у одисеју с вођен основним начелом „донкихотовског метода“ да нађе и „дели правду“, како због народа коме открива „скривену“ стварност, тако и због себе, славе и части свога Ја. Сервантес пише:

„Одиста, кад му већ памет би на измаку, наиђе му најчуднија мисао каква је икад дошла неком лудаку на овом свету, и то беше да му се учини уверљиво и нужно, како да би своју част увећао тако и да би својој држави служио, да постане витез луталица и да ходи свуд по свету с оружјем и коњем да тражи пустоловине и да се бави свиме оним о чему је читао да су се бавили витези луталице, светећи се за сваку увреду и излажући се приликама и опасностима где ће, када их приведе крају, стећи вечно име и славу." (Сервантес 2011: 39)

Овакав Дон Кихотов подухват данас би се, на заласку доба открића, могао назвати хуманитарном интервенцијом. Занет мислима о славној будућности, он производи привиде идеалних девица чију част треба заштити у недовољно добрим световима које треба ослободити. Главни проналазач новог века, Френсис Бекон, с идејом да су „барут и компас“ предуслов за праву освајачку пустоловину, 
креће у потрагу за новом Атлантидом у нади да ће побољшати овај свет и овладати историјом. Насупрот алтруистичком донкихотовском витезу, магбетовски ратник иде у освајање да би нешто узео само за себе. Али и један и други подразумевају да се све мора прилагодити њима, не трпе противљење, већ намећу своју историју као пут без алтернативе. „Технологија, модернизација и историја саткане су од костима које са себе узима Ја да би играло мишљену и измишљену улогу и дало форму извесности сопственом виртуелном постојању.“ (Петровић 2015: 111). Чињеница је да су фантазије и привиди постали неодвојиви део новог века. Тако и Дон Кихот од Манче живи у наспрамном свету где не може нити жели да разлучи привид од вида. Борба против измишљених непријатеља је одлика и једног и другог. Незнајући за Дан Вида, заслепљени својом историјом и Дон Кихот и Магбет задају и добијају тешке ударце, али ни један ни други се не осврћу нити се преиспитују. ${ }^{6}$ За њих је историја само милитантна ствар напредовања, наступања, марширања ка одредишту. Тако Дон Кихот, упркос племенитим намерама ослобођења своје девице - што заиста јако личи на ослобођење невиних пролетера који као ни витезови немају домовину, о чему сервантесовски пише Карл Маркс (који је такође прочитао много Хегелових витешких пустоловина о светском духу и његовом лутању напредовања кроз историју) - није у стању да предвиди далекосежне последице свог понашања. Он срља и не зна да постави питање постоји ли оно што гледа, или он то само тумачи, јер за то је потребно имати неку меру. „У свему је најважније сагледати меру. Тежња за побољшањем човековог положаја олако се претворила у незасити грабеж“ (Деспић и Петровић 2001: 158).

Мера је природа ствари, али она не може да се изуми јер се заснива на наслеђу. Преломни догађај у Магбету јесте када главни јунак прекида с наслеђем - убија свог пријатеља, великодушног краља и прекида традицију часног ратника, брише све из сећања како би могао да почини злочин. С друге стране, Дон Кихот од Манче раскида са стварним светом у тренутку када му се „,сасушио мозак и памет је изгубио“ (Сервантес 2011: 39) и преко себе пребацује рухо уображења како

6 Више о Дану вида види: Александар Петровић, О Дану вида и висарги, „Људи говоре“, 25/26, књ. 14, Торонто 2015, стр. 16 - 23. 
би несметано, без обзира на чињенице могао да ствара своју историју. Дон Кихот стално има идеју о ослобађању - али никада не размишља шта је слобода и шта значи ослободити некога. Једна његова хуманитарна пустоловина је одбрана дечака - слуге од господара који га је тукао када је „храбри витез“ наишао. Дон Кихот је решио проблем и наставио даље, не схватајући да ће дечаку због његовог мешања бити горе него што је било. Као што технологија решава један проблем, али истовремено ствара мноштво других. Елил нас упозорава да „напредујемо у решавању ових проблема, али једино на тај начин да када један решимо, суочимо се са другим. Такав је напредак технологије у нашем друштву“ (Елил 1962: 421): попут митске хидре којој, када се одсече једна, израсту две нове главе.

За разлику од Хамлета, који оклева јер зна да „бити спреман то је све“, Дон Кихот и Магбет своје потезе не одлажу ни на трен. Они журе као да је време стварно новац. Дон Кихот „није хтео више да чека са спровођењем своје намисли у дело, јер га је на то терала и потреба која се, како је веровао, јавила услед одуговлачења“ (Сервантес 2011: 42). Он жели да, као и Магбет, што пре досегне историјску славу. Када је у овом погледу реч о научно-технолошким истраживањима, она као да су руковођена својеврсним „витешким књигама“ о „откривању тајни природе“ и, опремљени својим лабораторијским и техничким инструментима, витезови од науке обећавају брзу промену света, измену тока историје освајајући тако част и славу. „У таквој револуционарној заслепљености, било да је она настала као незрелост или рђава намера, лежи главни проблем, јер је на тај начин изгубљена равнотежа спољњег и унутарњег, коју човек до данас није повратио“ (Деспић и Петровић 2001: 159).

Технологија се тако указује као очита последица губитка етике, коју схватамо као начело равнотеже, без обзира на то да ли је реч о племенитим циљевима научника, технолога, или магбетовским циљевима владања и моћи. Једно је неодвојиво од другога, јер наука је данас несумњиво ancilla политике. Власт над природом, из племенитих циљева или не, свакако је разорног карактера. Дон Кихот и Магбет се све више везују за своје заносе, губе сваку меру свог уплитања у поредак света, као што модерни човек у заносу не увиђа да 
решење не лежи у стварању нових технологија. У филму „Острво“, руског редитеља Павела Лунгина, монах баца чизме старешине, оца Филарета у ватру, а његов прекривач у воду. То у први мах изазива запрепашћење божјег човека, међутим убрзо схвата да га старац није решио драгоцености, већ привида да то јесу драгоцености његовог живота. Човек који је запао у опсену не може да пронађе нити да препозна себе, другог човека, или природу. Због тога се његов пут грана у два правца: донкихотовском, где ће бити сам са својим умишљајима, никада не долазећи до стварности и увек испребијан; или магбетовском, где ће варајући и убијајући друге прећи преко мора крви не би ли сустигао свој крајњи циљ, који ће подједнако добро бежати и ишчезавати сваки пут када му се чини да му је на дохват руке. И један и други образац се јасно оцртавају у модерном свету: „Човек мисли да се овим инструментом [машином] може послужити да како жели овлада природом, али не схвата да сама природа, у мери у којој је откривају технолошки инструменти, јесте стварна само у степену у коме ти инструменти могу да је мере“ (Кохански 1980: 22). 3бог тога ће стално бити приморан да се бори са дивовима, никада не схватајући да су то само ветрењаче. „Човек ће отуда моћи да влада стварношћу само дотле док буде био у стању да влада својим инструментима. Али доћи ће време кад ће ти инструменти превазићи његове способности, и тада ће он сасвим изгубити орјентацију. Што је још важније, онолико колико ти инструменти разлажу природу у најпростије елементе, човек је у стању да их синтетизује само као мртву материју а не као живу стварност“ (Кохански 1980: 22). Магбет тек пред смрт схвата колико је његов живот изгубио смисао. Тек тада увиђа да је круна празна нада, а да је борба била само пуко заваравање у коме је унапред осуђен да буде играчка вештица. „Самим тим што је пуна могућности, технологија је само празна форма, то јест, као најформалнија логика није кадра да одреди садржај живота.“ (Ортега и Гасет 1980: 33). У томе се огледа сва дубина пада.

После свега Магбет више не може да спава јер је „убио сан“, а Дон Кихот је затворен у свом сну без додира са природом ствари. Као што једног вештице лукаво обмањују да крене у отмицу круне, други је заваран витешким романима да отме девицу и буде нешто што 
није. Они на лажном идентитету покушавају да изграде живот да би се, као последица страсти за привидом све окренуло против њих. А то се не збива само хладном Магбету, или романтичном Дон Кихоту, то се дешава и нама. Све док технологија буде сведочила о губитку идентитета, и то рекламирала као „напредак“, неће бити могућности обнове. Хосе Ортега и Гасет у Медитацијама о Дон Кихоту увиђа потребу обнове Шпаније, али не механицистичку или материјалистичку, већ духовну кроз успостављање равнотеже. ${ }^{7}$ Као и Сервантес и Шекспир, и он осећа моралну одговорност да укаже да ће се донкихотовско лутање европског духа, магбетовско витлање мачем, окончати у тренутку када због губитка етике свет буду населила химерична бића за која ће „прво“ увек бити нешто „друго“.

\section{3. Производња илузије и судбина западног човека}

Запад ће наћи своју душу у западању када схвати да је Дон Кихот остарели западни Европљанин који је изгубио истинску веру колебајући се између филозофских становишта реализма и номинализма. Када се задовољио картезијанским минимумом да макар он као мислеће биће свакако мора да постоји, а све остало може али не мора, јасно је да је западни Европљанин донео одлуку у корист номинализма. „'Када ја употребим реч', рече Хампти Дампти прилично прекорним тоном, 'она значи оно што ја одаберем да треба да значи.'“ (Керол 2001: 223).

За средњовековног писца и његовог витеза истина је била тајна и била је са Богом, а витез на путу ка њој. Само беспрекорни витез могао се причестити Светим Гралом и учествовати у највећој мистерији. Међутим, Сервантес осећа нови век. Истину сада верификује субјект који је пре било какве евиденције утврдио да истину може изрећи само он са̂м. Ако је постојање непосредна последица Ја које мисли, онда Бог, много пре Лапласа и Ничеа, није потребан. Другим речима, победио је логичар који, како је рекао Честертон, „хоће да смести небеса у своју

7 Видети: Хосе Ортега и Гасет Медитације о Дон Kuхоту, Нови Сад: Издавачко предузеће Матице српске. 
главу. И онда је његова глава та која се расцепи.“ (Честертон 2012: 32). Зато је Кихоту довољно што он мисли да се сукобљава са дивовима, а не ветрењачама. Ако се њему сви детаљи уклапају у слику света коју из своје унутрашњости пројектује, ако је доживљава као истиниту, онда она мора бити истинита. Ја из мађионичарског полуцилиндра мишљења на запрепашћење свих вади зеца самог постојања. Кихот није усамљен лик у том протодекартовском поступку, као што ни Сервантес није једини приметио нови стадијум у развоју западноевропске свести. Зар није и Шекспиров Хамлет говорио:

„Могао бих бити затворен у ораховој љусци

и држати, да сам краљ бескрајног простора..." (Хамлет, II, 2)

Дон Кихот је довољан самоме себи, монада без прозора ка спољашњем свету. Он се самозаварава и отуда је и лака мета када други реше да се поиграју његовом болешћу. Једно од бизарнијих места у роману је када војвода и војвоткиња, пошто су прочитали први том о његовим авантурама, реше да конструишу читаву илузију са сценама из витешких романа, у шта не само да поверује Витез од Чемерне Прилике већ и Санчо Панса, иначе здравог разума и са обе ноге на земљи. Производња виртуелне стварности је у пуном јеку омогућена материјалним могућностима доконе аристократске породице која се обогатила златом из „откривеног“ Новог света. И у Хамлету је протагониста изрежирао тако убедљиву представу да се и са̂м крвник Клаудије потресао и тиме одао свој злочин. Сетимо се и Буре у којој један једини лик Просперо управља свим догађајима, такорећи самостално режира читаву драму, да би се на крају све распршило и он ломио свој штап уз речи:

$$
\begin{gathered}
\text { „Ми смо грађа од које се праве } \\
\text { Снови, и наш мали живот } \\
\text { Окружен је сном.“ (Бура, IV, 1) }
\end{gathered}
$$

Шта год да је Шекспир мислио рекавши да смо сви начињени од снова, у лику Проспера и његовим успешним махинацијама указао је на моћ обмане и њен извор. Просперо је волшебник који влада 
магијом, односно оним што ће у савременом свету злослутно мутирати у науку и технологију. Суштина је иста: манипулација материјом, чулним, опипљивим ради 'производње', 'резултата', 'ефикасности', 'брзине', 'удобности'. Сервантесови војвода и војвоткиња и Шекспиров Просперо заправо најављују савремени брак новца и науке, трке за открићима што је непосредни увод у ратове. Зар није садистичко поигравање војводе и војвоткиње несрећним поремећеним идалгом најава reality show програма и шарених револуција у којима се на готово истоветан начин медијски и политички могули поигравају људима гладних бољег живота у будућности? Или, још горе, није ли и сама историја појам који је искован у мудрословним витешким списима просвећених филозофа који нас убеђују да ће једном ослободити девице из заточеништва? Шта су пропагандне машинерије масовних медија и услужни системи јавног образовања ако не врхунско произвођење историје као илузије у које треба поверују читаве популације да би купиле производе или подржале ратове? Историја је и primum movens и causa finalis створене илузије, а Шекспир и Сервантес су открили где тражити њене антрополошке корене: међу доконим великашима, технолозима, опсенарима, пробисветима и онима који би да у мраку, „верујући да их тада не види нико“ зграбе божанску честицу и заточе је у трезор да би се јалово оплодила.

И Магбет и Маттоглави идалго дон Кихот од Манче се завршавају на исти начин. Првобитни типични јунак витешког романа је врло млад човек, чак дечак, на почетку животног пута, пун снаге. Насупрот томе, Сервантесов дон Кихот је стар, онемоћао, савладан временом. Јунак витешког романа своју пустоловину често је крунисао свадбом и успехом. Дон Кихот на крају своје приче умире без потомства, не постигавши никакав успех. Потпуно исцрпљени од борбе, и Магбет и Дон Кихот се урушавају на крају животног пута. Није чудно што су ова дела врло слична - Сервантес и Шекспир долазе из различитих монархија; међутим, они исказују у различитим видовима исти дух доба открића које је деконструисало етику равнотеже и живи свет који на њој почива. Зато из ових дела можемо да сагледамо будућност доба открића. Никакви научни експерименти и прорачуни нису потребни за овако нешто; књижевност је довољна. „Унутрашње огра- 
ничење науке, као и одговарајућа ограничења технологије, већ казују да наука и технологија у ствари нису у стању да обезбеде никакав крајњи интегришући принцип културе“ (Лодриер, 1980: 69). Није тешко домислити будућност: сви циљеви које је технологија поставила су неодрживи, јер како Александар Кохански упозорава „све док се буде чврсто придржавало свог научно-технолошког усмерења, човечанство ће се непрестано кретати од кризе до кризе" (Кохански, 1980: 23). Другим речима, доћи ће до циља колико Дон Кихот и Магбет.

Шта је, међутим, са новим европским човеком и будућношћу у коју он верује? Дон Кихот неће умрети од витешких рана и болести, већ сломљен разочарањем. Његово одбацивање витешких романа подједнако је жучно као претходна опсесија њима. Сервантес нам је приказао како се велика огорченост и смртоносна туга јављају после слома велике опсене. Човек који је преко свих граница развио фантазију уздигавши је до погледа на свет и све менталне снаге упрегао да га оправда, на крају је разочарао самога себе. Схватио је да не верује ни у шта. Дон Кихот је као комуниста који хоће да се напречац претвори у националисту, националиста у глобалисту или либерал који би под старе дане да се претвори у конзервативца. Као симбол колективног духа, Дон Кихот је увек-модерно-трансформисани Европљанин данас убеђен у једну стварност, а сутра у сасвим супротну. Он припада Европи која одлази у 'спасилачке ратове' за које ће се касније извињавати, јер у мору крви није спасена ни једна девица; која је колонизовала пола света да би по универзитетима продавала антиколонијални дискурс и оријентализам; која је хиљаду година усавршавала пропаганду и ширила догму да би кроз постмодернизам, постструктурализам и конструктивизам убеђивала да је све релативно. Све подсећа на сцену из Алисе у земљи иза огледала у којој се Алиса и краљица споре око веровања у невероватне ствари:

„Алиса се насмејала. „Не вреди покушавати“, рекла је: „не може се веровати у немогуће ствари.“ „Рекла бих да ниси много вежбала“, рече Краљица. „Када сам била твојих година, увек сам то радила пола сата дневно. Боже, понекад сам веровала у чак шест немогућих ствари пре доручка." (Керол, 2001: 210-211).

312 
Европа је цивилизација Дон Кихота, махнитог субјекта који хоће да све постави из самога себе и да, облачећи се и понашајаући се као живи музеј, доврши пресецање корена традиције и на брзину, као сметњу за progressus ad infinitum, одбаци и антику и хришћански идентитет који није идеалан (нити то треба да буде), али је дуги низ векова везивно ткиво и оправдање европске културе. Отуда се свештеник тако значајно јавља у Дон Кихоту и улаже све напоре да мученика спаси. Ипак, крај и преобраћење Кихотово не дају нарочиту наду. Кихот готово да понавља речи које је све време слушао и чак каже да својој сестричини неће оставити ништа у наследство уколико се уда за некога ко је макар и чуо за витешке романе. Дон Кихот је овим коначно промашио мету. Јер није проблем у витешким романима (у једном тренутку, при крају романа, дон Кихот прави планове да постане јунак пасторалних идила), већ у њему самом који није у стању да разликује истину од лажи, утваре од стварности. Постмодернизам све дугује Дон Кихоту и у томе је наша коб јер како време иде витез постаје све савременији. На крају је, у његовој готово алергијској реакцији на књиге које је до тада обожавао ипак највише испливала - жустрина. Дон Кихот не делује као неко ко је нашао смирење, већ као човек који је без равнотеже увек приморан да жустро открије новог непријатеља, нове ветрењаче, нови проблем који ће му скретати пажњу да не окрене поглед ка себи. Историја је донкихотизам без краја.

\section{ЛИТЕРАТУРА}

Archibald, Elizabeth. "Ancient Romance". Corinne Saunders (ed.), A Companion to Romance: from Classical to Contemporary. Oxford: Blackwell Publishing Ltd., 2007; $1^{\text {st }}$ ed. 2004, 10-25. Штампано.

Auerbach, Erich. Mimesis: The Representation of Reality in Western Literature. Princeton University Press/Princeton and Oxford 2003. Printed.

Barron, W. R. J. English Medieval Romance. London and New York: Longman, 1987. Printed.

Bloch, Ernst. The Utopian Function of Art and Literature: Selected Essays. (translated bym Jack Zipes and Frank Mecklenburg). Cambridge, Mass.: MIT Press, 1988. Printed.

Brewer, Derek. Symbolic Stories. London and New York: Longman, 1988. Printed. 
Chesterton, G.K. Orthodoxy. Chicago: The Moody Bible Institute, 2009. Printed.

Ellul, Jacques "The Technological Order". Technology and Culture, Vol. 3, No. 4, Proceedings of the Encylopaedia Britannica Conference on the Technological Order (Autumn, 1962), 394-421. Printed.

Ellul, Jacques The Technological Bluff, Wm. B. Eerdmans Publishing Co, 1990. Printed.

Carroll, Lewis. Alice's Adventures in Wonderland \& Through the LookingGlass. Hertfordshire, UK: Wordsworth Edition Ltd., 2001

Petrović, Lena. Quest Myth in Medieval English Literature. Niš: Izdavačka jedinica Univerziteta u Nišu, 1999. Printed.

Šekspir, Vilijam. Hamlet, danski kraljević. Beograd: Izdavačko preduzeće "Rad", 1966. (Sima Pandurović i Živojin Simić). Štampano.

Shakespeare William. The Complete Works of William Shakespeare. London: Wordsworth Editions, 1996, 670-714; 858-885. Printed.

Stevens, John. Medieval Romance: Themes and Approaches. New York: The Norton Library, 1974. Printed.

Tillich, Paul. The Shaking of the Foundations. Eugene, Oregon: Wipf and Stock Publishers, 2011 (Previsously published by Charles Scribner's Sons, 1948). Printed.

Vinaver, Eugène. The Rise of Romance. Oxford: Oxford University Press, 1971. Printed.

Wark, McKenzie. Molecular Red: Theory for the Anthropocene (On Alexander Bogdanov and Kim Stanley Robinson), Web. 19.5.2015. http:// www.e-flux.com/journal/molecular-red-theory-for-the-anthropocene-on-alexander-bogdanov-and-kim-stanley-robinson

Wilson Anne. Traditional Romance and Tale: How Stories Mean. Ipswich: D. S. Brewer, 1976. Printed.

Деспић, Александар и Петровић, Александар. На крају века: од вртоглавог успона до етичког пада. Флогистон, бр.11, 2001, 151-175. Штампано.

Колаковски, Лешек. Присутност мита, Београд: Печат, 1989. Штампано.

Кохански, Александар, Доба просветитељства 1689-1989, у: Технологија, Београд: Видици, бр. 5-6, 1980, 21-23. Штампано.

Лодриер, Ж., Одређивање проблема будућности, у: Технологија, Београд: Видици, 1980, бр. 5-6, 69-72. Штампано.

Лунгин, Павел. филм Острво, 2006. Веб. 19.5.2016. https://www.youtube.com/watch?v=sAPAzjymKyM 
Мамфорд, Луис."Тиранида сата“, у: Технологија. Београд: Видици, бр. 5-6, 1980, 47-48. Штампано.

Мелетински, Јелеазар М.. Увод у историјску поетику епа и романа (превела Радмила Мечанин). Београд: Српска књижевна задруга, 2009. Штампано.

Милошевић, Никола, „Дон Кихот и нихилизам“. Антрополошки есеји. Београд: Нолит, 1964, 104-129. Штампано.

Ортега и Гасет, Хозе. „Човек технолог", у: Технологија, Београд: Видици, бр.5-6, 1980,25-35. Штампано.

Ортега и Гасет, Хозе. Медитације о Дон Кихоту, Нови Сад: Издавачко предузеће Матице српске, 2000. Штампано.

Петровић, Александар et al. Речник технологије, Београд: Видици, бр. 1-2, 1981. Штампано.

Петровић, Александар. „О Речнику технологије и духу привида“. Бошковић, Душан и Александар Петровић (ур.), Повратак из земље змајева, Речник технологије - 33 године после, Београд: Институт за филозофију и друштвену теорију, 2015, 93-119. Штампано.

Петровић, Михајло. Феноменолошко пресликавање. Београд: Српска краљевска академија, 1933. Штампано.

Сервантес, Мигел де. Маштоглави идалго дон Кихоте од Манче (превела: Александра Манчић). Београд, Службени гласник, 2011. Штампано.

Стојановић Коста. Рam и прогрес, књ. 3. и 4. Београд: Мисао, 1920. Штампано.

Тилих, Паул. Дрмање темеља, у: Технологија, Београд: Видици, бр. 5-6, 1980, 79-80. Штампано.

Фрај, Нортроп. Анатомија критике. Нови Сад: Orpheus, НОлИТ. Штампано.

Хераклит, О природи, Београд: Култура, Мала филозофска библиотека. Превео и објаснио Мирослав Марковић, 1954. Штампано.

Шекспир, Вилијам. Бура. Београд : Вајат : Српска књижевна задруга: БИГЗ, 1993. Штампано. 


\title{
Aleksandar Petrović \\ Danko Kamčevski \\ Aleksandra Stevanović
}

\section{THE ENDLESS QUIXOTISM}

\begin{abstract}
Summary
This paper is an attempt to grasp Cervantes and Shakespeare from the perspective of cultural anthropology and reveal these authors as two vital prophets of European culture. The idea was to transpose these authors through the wormhole of time and into the world we are living in by using the principle of the least possible illusion. What they really thought of course remains outside the domain of our abilities to know, but their major works are considered a matter of deconstructing the limits of truth and deception, out of which arises the paramount illusion - technology. Their literary characters have crossed all boundaries and showed the consequences of life without balance in which the fallen ethics, through dramaturgy of history, assumes the pretense of ingenious technology.
\end{abstract}

Keywords: ethics, balance, technology, Don Quixote, Macbeth, Europe. 